\title{
Protein Quality of Amaranth Grains Cultivated in Ethiopia as Affected by Popping and Fermentation
}

\author{
Endale Amare ${ }^{1,2^{*}}$, Claire Mouquet-Rivier ${ }^{3}$, Adrien Servent ${ }^{4}$, Gilles Morel ${ }^{4}$, \\ Abdulaziz Adish ${ }^{5}$, Gulelat Desse Haki² \\ ${ }^{1}$ Wolaita Sodo University, Wolaita Sodo, Ethiopia \\ ${ }^{2}$ Center for Food Science and Nutrition, Addis Ababa University, Addis Ababa, Ethiopia \\ ${ }^{3}$ IRD UMR 204 "Prévention des Malnutritions et des Pathologies Associées" (Nutripass), \\ IRD/Montpellier 2/Montpellier 1, Montpellier, France \\ ${ }^{4}$ CIRAD, Département Persyst, UMR Qualisud, Montpellier, France \\ ${ }^{5}$ Micronutrient Initiative, Addis Ababa, Ethiopia \\ Email: ${ }^{*}$ endal97@gmail.com
}

Received 5 November 2014; revised 7 December 2014; accepted 30 December 2014

Copyright (C) 2015 by authors and Scientific Research Publishing Inc.

This work is licensed under the Creative Commons Attribution International License (CC BY).

http://creativecommons.org/licenses/by/4.0/

c) (i) Open Access

\section{Abstract}

The effect of popping and fermentation on protein quality of three different varieties of amaranth grains cultivated in Ethiopia was evaluated. Total lysine content of the grains was higher than that of commonly available cereals but close to that of legumes. Methionine and cysteine contents in the grains were also higher than that found in cereal and legume proteins. Percentage of total indispensable amino acids, excluding tryptophan, was $43 \%-49 \%$, which was higher than WHO reference pattern (31\%). Popping resulted in $36 \%$ and $37 \%$ reduction in total lysine and cysteine contents, respectively, whereas fermentation reduced cysteine, lysine and methionine contents by $16 \%, 20 \%$ and $20 \%$, respectively. From the free amino acids, histidine was the major indispensable amino acid but threonine was not detected. During popping, all free amino acids, except threonine, were reduced. On the other hand, fermentation significantly increased $(p<0.01)$ most amino acids except arginine, which was significantly decreased $(p<0.01)$, and tyrosine and glutamic acid, for which no change was observed. Popping decreased in vitro protein digestibility (IVPD) by $8.3 \%$ - 17.1\% while fermentation increased IVPD by $4.8 \%-7.5 \%$. Substitution of amaranth for wheat and/or maize during complementary food formulation could contribute much to the daily requirements of indispensable amino acids of young children.

\section{Keywords}

Amaranth Grain, Indispensable Amino Acids, Popping, Fermentation, Protein Digestibility,

*Corresponding author. 


\section{Complementary Food}

\section{Introduction}

The genus Amaranthus belongs to the family Amaranthaceae. It has a huge biodiversity and several of them are cultivated as leafy vegetables, grains, and ornamental plants while others are weeds [1]. Among all the species, Amaranthus caudatus, Amaranthus hypochondriacus and Amaranthus cruentus are mainly cultivated for their seeds [2] [3].

Amaranth was neglected from the food table for many decades after the arrival of the Spanish conquistadors in Latin America as it was used in ceremonial dishes associated with human sacrifice by the Aztecs [1]. It is known for its high tolerance to arid conditions and poor soils, its resistance to drought, heat, and pests, and its ability to adapt to environments where conventional cereal crops do not grow well. Amaranth can thus contribute to food security, especially in resource poor setting [1] [4]. Despite the very wide distribution of amaranth in Ethiopia, it is cultivated as intercropped with sorghum and maize mainly by Me'enit people who live in the Southern Nations, Nationalities and Peoples Region (SNNPR). The most frequent mode of consumption of amaranth grains by these people is after popping and milling, and by mixing the flour with other cereal flours such as teff, sorghum, barley and wheat to prepare bread, injera and porridge.

Concerning the nutritional quality, protein content of amaranth grains is higher than that of most common cereals [5] [6]. In addition, amaranth grains contain useful amino acid profile [6]-[8]. Despite the high protein content and interesting amino acid profile of amaranth grains, the overall protein quality is dependent on the digestibility. In this regard, popping, the most commonly used processing method for amaranth, and fermentation, which is widely used in Africa to prepare cereal based foods like injera, can influence protein digestibility [9]-[12]. This is due to the fact that these techniques are associated with the decrease in the content of exogenous factors such as tannin, phytate and trypsin inhibitors which are responsible for reducing protein digestibility.

Other processing techniques such as boiling, microwave cooking, and autoclaving also affect protein digestibility. According to El-Adawy et al. (2002) [10], boiling, microwave cooking and autoclaving improved the digestibility of chickpea protein. On the other hand, Nunes et al. (2004) [13] reported that cooking decreased the digestibility of sorghum and maize protein. Similar controversies surround the effect of popping on the digestibility of amaranth protein. According to a study conducted by Gamel et al. (2004) [6], popping improved the IVPD whereas Pedersen et al. (1987) [5] and Písaříková et al. (2005) [8] reported a decrease in IVPD during popping of amaranth. On the other hand, fermentation has been found to improve in vitro protein digestibility of cereals due to the degradation of protein binding molecules [9] [11] [12].

In developing countries like Ethiopia, complementary foods for young children are mainly prepared from mixes of cereals and legumes. It is known that among essential amino acids, legumes are rich sources of lysine but lack methionine and cysteine, while cereals are rich in these two amino acids but are poor sources of lysine. Mixing legumes and cereals during complementary food formulation is a common strategy to meet essential amino acid requirements. However, a too high proportion of legumes sometimes compromise the acceptability of the product and, in addition, legumes contain high levels of antinutritional factors. It is thus advisable to reduce the proportion of legumes in complementary food formulation.

The aim of the present study was, therefore, to evaluate the protein quality of three different varieties of amaranth grains cultivated in Ethiopia in the raw state and after popping or fermentation by analyzing the contents of free and total amino acids and in vitro protein digestibility of amaranth grain porridge to assess its potential application as an ingredient for complementary food formulation.

\section{Materials and Methods}

\subsection{Materials}

Three different varieties of amaranth grains, white, red and brown in color, were purchased from six farmers in Chat Kebelle, Bench Majji Zone, in the Southern Nations, Nationalities and Peoples region, Ethiopia. Composite samples of each variety prepared from the grains of the six origins were sorted, cleaned and washed to remove immature seeds, sand and soil. The washed seeds were sun dried, milled and sieved in a 0.425 mm sieve. The flour was stored at $4^{\circ} \mathrm{C}$ until further analysis. 


\subsection{Solvents, Chemicals and Reagents}

Citrate buffer $\mathrm{pH} 2.2$ and ninhydrin reagent were purchased from Biochrom (France). Sodium hydroxide (BioXtra, $\geq 98 \%$ acidimetric), pellets (anhydrous), L-Norleucine (N8513 suitable for amino acid analysis), aminobutyric acid (A2129; $\geq 99 \%$ ), methanesulfonic acid (M4141; $4 \mathrm{M}$ with $0.2 \%(\mathrm{w} / \mathrm{v})$ tryptamine) were purchased from Sigma-Aldrich (Saint-Louis, Missouri, USA). Amino acid standards (AA-S18; analytical standard), hydrochloric acid $0.1 \mathrm{~N}$ were purchased from Fluka (Fluka Chemicals, Buchs, Switzerland). All reagents and chemicals used were of analytical grade.

\subsection{Processing Methods}

\subsubsection{Popping}

Sun dried seeds were placed in a hot clay pan for 10 - 15 seconds until they popped. The popped grains were milled to pass through a $0.425 \mathrm{~mm}$ sieve and stored in polyethylene bags at $4^{\circ} \mathrm{C}$.

\subsubsection{Fermentation}

Natural fermentation was carried out according to the method described in [14] with modifications. Briefly, 250 $\mathrm{g}$ of flour prepared from raw amaranth grains was mixed with $500 \mathrm{ml}$ distilled water and then left to ferment spontaneously for $48 \mathrm{~h}$ at room temperature. The sample was mixed, transferred into aluminum cups and dried in a hot oven (Heraeus UT 5042, Germany) at $50^{\circ} \mathrm{C}$ for $20 \mathrm{~h}$. The dried sample was then ground to pass through a $0.425 \mathrm{~mm}$ sieve and stored in polyethylene bags at $4^{\circ} \mathrm{C}$.

\subsubsection{Preparation of Gruels}

Amaranth gruels were prepared using the method described in [15]. Briefly, the flour was mixed with cold deionized water into slurry and cooked with continuous stirring over a hot plate for $5 \mathrm{~min}$ after the mixture starts to boil. The gruel was allowed to cool and sample was taken for protein digestibility experiment.

\subsection{Chemical Analysis}

\subsubsection{Protein and Dry Matter Measurement}

The nitrogen content of all Samples was determined using Kjeldhal method and a conversion factor of 5.85 was used [16]. The dry matter content was determined by oven drying at $105^{\circ} \mathrm{C}$ to a constant weight.

\subsubsection{Free and Total Amino Acid Analysis}

1) Extraction procedure

a) Free amino acids

Free amino acids were analyzed following the method used by Moore et al. (1958) [17] with modifications. Briefly, $150 \mathrm{mg}$ of sample was weighed and placed in a sealable test tube. To this, $50 \mu \mathrm{l}$ of internal standard Norleucine $(25 \mu \mathrm{M})$ and $4.95 \mathrm{ml}$ of citrate buffer ( $\mathrm{pH} 2.2)$ were added. The solution was mixed for $1 \mathrm{~h}$ on a rotational shaker. All extractions were performed in triplicate.

b) Total amino acids

Samples (10 - $20 \mathrm{mg}$ ) of dried flour were weighed in a Schlenk tube and $50 \mu \mathrm{l}$ of $25 \mu \mathrm{M}$ Norleucine and 450 $\mu \mathrm{L}$ of $4 \mathrm{M}$ methanesulfonic acid were added. The tube was flushed with nitrogen, closed and heated at $150^{\circ} \mathrm{C}$ for $2 \mathrm{~h}$. After cooling, $450 \mu \mathrm{L}$ of $4 \mathrm{M} \mathrm{NaOH}$ was added to the hydrolysate, which was diluted to $5 \mathrm{ml}$ with a loading buffer (citrate buffer at $\mathrm{pH}$ 2.2). All extractions were performed in triplicate.

2) Amino acid analysis

Sample extracts for free and total amino acid analysis were filtered using a $0.45 \mu \mathrm{m}$ membrane filter and injected into the amino acid analyzer (Biochrom 30+, Biochrom, France), using a lithium cation exchange resin column and ninhydrin as detection compound. All total and free amino acid contents were determined except total tryptophan, which is the most fragile amino acid and is destroyed by the extraction procedure. Amino acid standards were also run in a similar way as the samples.

\subsubsection{Determination of in Vitro Protein Digestibility}

In vitro protein digestibility was determined according to the method of Akeson and Stahmanna (1964) [18] with modifications. To $10 \mathrm{~g}$ of amaranth porridge (with approximately 10\% assumed DM content), $15 \mathrm{ml}$ of 
0.16 M HCl containing $1.5 \mathrm{mg}$ pepsin (Sigma, P-7000, 14,900 u/mL) was added and incubated at $37^{\circ} \mathrm{C}$ for $2 \mathrm{~h}$ in a shaking water bath. The resulting suspension was neutralized with $7.5 \mathrm{ml}$ of $0.32 \mathrm{M} \mathrm{NaOH}$ and treated with 4 $\mathrm{mg}$ of pancreatin (Sigma, P-7545, 8*USP specifications) in $7.5 \mathrm{ml}$ of $0.32 \mathrm{M}$ phosphate buffer (pH 8.0). The mixture was incubated for an additional $2 \mathrm{~h}$ at $37^{\circ} \mathrm{C}$. Enzyme blank was prepared by incubation under the same conditions except that the sample was omitted. After incubation, the sample was treated with $10 \mathrm{ml}$ of $10 \%$ trichloroacetic acid (Sigma) to remove undigested protein and larger peptides and centrifuged at $5000 \mathrm{~g}$ for 20 min at room temperature. The solution was filtered using Whatman No. 1 filter paper, and the protein in the supernatant was then determined using Kjeldahl method.

\subsubsection{Amino Acid Score and Protein Digestibility Corrected Amino Acid Score}

The amino acid score (AAS) is the ratio of the amino acid content in the protein of a food/diet to the content of the same amino acid in the requirement pattern. The score determines the effectiveness with which absorbed dietary nitrogen can meet the indispensable amino acid requirements at the safe level of protein intake. This is thus a measure of the actual amounts of individual amino acids in a food with respect to the need for this amino acid. And the quality of the protein will finally depend on the indispensable amino acid for which the AAS is the lowest. However, AAS does not account for the digestibility of the protein. Therefore, another scale called the protein digestibility corrected amino acid score (PDCAAS) was adopted by WHO/FAO (2007) [19] to better explain digestibility in relation to the needs of humans and the scoring of foods (Equation (1)):

$$
\text { PDCAAS }=\text { amino acid score } \times \text { digestibility }
$$

\subsection{Calculation of the Percentage Contribution of Amaranth to Estimated Amino Acid Requirements}

From the amino acid data, intakes of indispensable amino acids were calculated for comparison with the WHO estimated needs [19], assuming breast-fed infants aged 6 - 23 months consume the recommended daily ration size of $50 \mathrm{~g} / \mathrm{d}$ dry weight complementary food [20]. The amount of cereal used in complementary food formulation was assumed to be 64\% [21] and, assuming that this amount of cereal is replaced by amaranth, its percent contribution to the daily indispensable amino acid requirements was calculated.

\subsection{Data Analysis}

All measurements were done in triplicate and statistical analyses were performed using the software Statgraphics plus 5.1 (Statpoint, Warrenton, USA). Two-way ANOVA was applied to the experimental data and means were separated using Fischer's least significant difference tests with a probability $\mathrm{p}<0.05$.

\section{Results and Discussion}

\subsection{Protein, Total and Free Amino Acid Content in Amaranth Grains}

Table 1 indicates the crude protein, and total and free amino acid contents in raw amaranth grains. The protein contents of raw white, red and brown amaranth were 13.9, 15.2 and 15.5 g/100g DM, respectively. These results are in agreement with the results reported by Pedersen et al., (1987) [5]. Kaur et al. (2010) [3] also reported that 14.8\% - 16.8\% protein has been obtained from 11 lines of Amaranthus caudatus species grown in India.

The amount of almost all essential amino acids in the raw samples was above the new FAO/WHO standard pattern for all age groups [19] implying that there is no limiting amino acid in amaranth grains considered in this study. Tryptophan, one of the indispensable amino acids, was not analyzed in this study but Gamel et al. (2004) [6] reported that their amaranth samples also contained appreciable amounts of tryptophan.

The lysine content of raw amaranth ranged from 65 to $74 \mathrm{mg} \cdot \mathrm{g}^{-1}$, protein which is close to the lysine contents in legumes (70 - $75 \mathrm{mg} \cdot \mathrm{g}^{-1}$ protein) including chickpeas, cowpeas and lentils but twice higher than that found in many other cereals, such as barley, wheat, rice, rye and maize: $22-37 \mathrm{mg} \cdot \mathrm{g}^{-1}$ protein. Methionine and cysteine contents were ranged from 24 to 29 and 43 to $51 \mathrm{mg} \cdot \mathrm{g}^{-1}$ protein, respectively, which were higher than that found in the legumes and cereals mentioned above [22] [23]. The concentrations of essential amino acid in amaranth grains cultivated in Ethiopia (Table 1) were in good agreement with those reported by Chavez-Jauregui et al. (2000) [24] and slightly higher than those reported by Gamel et al. (2004) [6] in Amaranthus caudatus.

The percentage of indispensable amino acids, excluding tryptophan, tryptophan, was highest in raw white 
Table 1. Total and free amino acid profile $\left(\mathrm{mg} \cdot \mathrm{g}^{-1}\right.$ protein) of three varieties of raw amaranth grains ${ }^{\dagger}$.

\begin{tabular}{|c|c|c|c|c|c|c|c|}
\hline \multirow{3}{*}{$\begin{array}{c}\text { Protein (g/100g DM) } \\
\text { Amino acid }\end{array}$} & \multirow{2}{*}{\multicolumn{2}{|c|}{$\begin{array}{c}\text { White amaranth } \\
13.88 \pm 0.16\end{array}$}} & \multirow{2}{*}{\multicolumn{2}{|c|}{$\begin{array}{c}\text { Red amaranth } \\
15.15 \pm 0.08\end{array}$}} & \multirow{2}{*}{\multicolumn{2}{|c|}{$\begin{array}{c}\text { Brown amaranth } \\
15.53 \pm 0.24\end{array}$}} & \multirow{3}{*}{$\begin{array}{l}\text { Standary } \\
\text { pattern" }\end{array}$} \\
\hline & & & & & & & \\
\hline & Total & Free & Total & Free & Total & Free & \\
\hline Cysteine $^{*}$ & $50.7 \pm 8.3$ & $0.9 \pm 0.0$ & $42.7 \pm 3.0$ & $1.3 \pm 0.2$ & $45.5 \pm 4.3$ & $0.7 \pm 0.1$ & \\
\hline Histidine $^{*}$ & $37.2 \pm 3.1$ & $1.4 \pm 0.1$ & $33.9 \pm 2.5$ & $1.5 \pm 0.0$ & $34.8 \pm 2.0$ & $1.2 \pm 0.1$ & 18.0 \\
\hline Isoleucine $^{*}$ & $39.4 \pm 3.0$ & $0.4 \pm 0.1$ & $37.2 \pm 2.6$ & $0.4 \pm 0.1$ & $34.9 \pm 2.4$ & $0.3 \pm 0.1$ & 31.0 \\
\hline Leucine $^{*}$ & $67.1 \pm 2.9$ & $0.4 \pm 0.0$ & $60.8 \pm 2.6$ & $0.4 \pm 0.0$ & $59.5 \pm 0.2$ & $0.2 \pm 0.0$ & 63.0 \\
\hline Lysine $^{*}$ & $73.9 \pm 2.3$ & $1.2 \pm 0.0$ & $66.7 \pm 7.2$ & $1.1 \pm 0.0$ & $65.3 \pm 1.6$ & $0.9 \pm 0.0$ & 52.0 \\
\hline Methionine $^{*}$ & $28.8 \pm 0.5$ & $0.4 \pm 0.1$ & $23.8 \pm 3.4$ & $0.5 \pm 0.2$ & $25.8 \pm 0.7$ & $0.3 \pm 0.1$ & \\
\hline Phenylalanine* & $46.5 \pm 3.6$ & $0.2 \pm 0.0$ & $42.6 \pm 1.4$ & $0.2 \pm 0.0$ & $40.4 \pm 3.5$ & $0.1 \pm 0.0$ & \\
\hline Threonine ${ }^{*}$ & $40.3 \pm 1.9$ & $0.0 \pm 0.0$ & $35.0 \pm 3.4$ & $0.0 \pm 0.0$ & $36.7 \pm 1.1$ & $0.0 \pm 0.0$ & 27.0 \\
\hline Tryptophan* & ND & $1.0 \pm 0.0$ & ND & $1.4 \pm 0.1$ & ND & $0.7 \pm 0.0$ & 7.4 \\
\hline Valine $^{*}$ & $48.3 \pm 1.2$ & $0.7 \pm 0.1$ & $42.0 \pm 4.6$ & $0.7 \pm 0.1$ & $41.3 \pm 2.7$ & $0.5 \pm 0.1$ & 42.0 \\
\hline Alanine & $44.0 \pm 2.0$ & $1.1 \pm 0.0$ & $38.2 \pm 5.8$ & $0.5 \pm 0.1$ & $39.0 \pm 1.5$ & $1.0 \pm 0.0$ & \\
\hline Arginine & $109.8 \pm 8.0$ & $1.6 \pm 0.0$ & $102.2 \pm 10.0$ & $3.6 \pm 0.3$ & $100.6 \pm 4.0$ & $1.0 \pm 0.0$ & \\
\hline Aspartic acid & $94.4 \pm 5.2$ & $1.1 \pm 0.0$ & $86.0 \pm 9.3$ & $2.2 \pm 0.1$ & $89.4 \pm 10.0$ & $1.2 \pm 0.0$ & \\
\hline Glutamic acid & $203.5 \pm 14.0$ & $2.9 \pm 0.0$ & $183.5 \pm 15.0$ & $4.6 \pm 0.3$ & $181.8 \pm 3.0$ & $1.8 \pm 0.0$ & \\
\hline Glycine & $100.1 \pm 4.0$ & $1.3 \pm 0.0$ & $89.1 \pm 6.4$ & $0.4 \pm 0.1$ & $100.0 \pm 4.0$ & $1.1 \pm 0.0$ & \\
\hline Proline & $135.7 \pm 25.6$ & $2.4 \pm 0.0$ & $125.0 \pm 30.0$ & $3.7 \pm 0.2$ & $118.4 \pm 17.4$ & $1.5 \pm 0.0$ & \\
\hline Serine & $65.5 \pm 4.0$ & $1.3 \pm 0.2$ & $58.5 \pm 4.8$ & $2.1 \pm 0.1$ & $68.9 \pm 1.6$ & $0.6 \pm 0.0$ & \\
\hline Tyrosine & $52.9 \pm 6.0$ & $0.5 \pm 0.0$ & $45.8 \pm 2.7$ & $0.7 \pm 0.0$ & $49.7 \pm 3.4$ & $0.4 \pm 0.0$ & \\
\hline $\mathrm{AAA}^{\S}$ & $99.4 \pm 6.3$ & & $88.4 \pm 2.6$ & & $90.1 \pm 3.4$ & & 46.0 \\
\hline $\mathrm{SAA}^{z}$ & $79.5 \pm 7.9$ & & $66.5 \pm 5.9$ & & $71.3 \pm 4.9$ & & 26.0 \\
\hline $\mathrm{NH}_{3}$ & $78.3 \pm 6.1$ & $3.2 \pm 0.0$ & $70.0 \pm 14.3$ & $2.0 \pm 0.1$ & $76.6 \pm 12.2$ & $1.4 \pm 0.1$ & \\
\hline
\end{tabular}

${ }^{\dagger}$ Values are means of results obtained in triplicate \pm SD expressed in $\mathrm{mg} \cdot \mathrm{g}^{-1}$ protein and means followed by different letters in the same row are significantly different at $\mathrm{p}<0.05 .{ }^{\S} \mathrm{AAA}$ : aromatic amino acids (phenylalanine and tyrosine). ${ }^{\vee} \mathrm{SAA}$ : sulfur amino acids (cysteine and methionine). ND: not determined. "Indispensable amino acids [19]. "Standard FAO/WHO reference pattern for indispensable amino acids for children aged 1 - 2 years [19].

amaranth (49\%) followed by $43 \%$ in both raw red and brown amaranth. These values are higher than the reference protein pattern for 1 - 2 years old children (31\%). The amaranth amino acid profile thus provides a good balance of total indispensable amino acids, and some of the limiting amino acids, especially lysine in cereals and methionine and cysteine in legumes, could be complemented by amaranth.

The free amino acid content of the three varieties of raw amaranth is listed in Table 1 . The main essential free amino acid was histidine followed by lysine and tryptophan with $1.2-1.5,0.9-1.2$ and $0.7-1.4 \mathrm{mg} \cdot \mathrm{g}^{-1}$ protein, respectively. A study by Nimbalkar et al. (2012) [25] on Amaranthus hypocondriacus grain reported that the top three essential free amino acids were threonine, phenylalanine, and methionine and that the amount of threonine was twice that of the other free amino acids. However, in the present study, no free threonine was detected in any of the three varieties of amaranth grains, and glutamic acid and proline were the main non-essential free amino acids with values in the range of 1.8 to 4.6 and 1.5 to $3.7 \mathrm{mg} \cdot \mathrm{g}^{-1}$ protein, respectively.

\subsection{Effect of Popping and Fermentation on Total Amino Acid Content}

Popping decreased the amount of six amino acids including three indispensable amino acids: lysine, methionine, 
and cysteine. The decrease was highest for lysine and cysteine and reached 36\% and 37\% reduction, respectively (Table 2). In a study conducted in two different species of amaranth (Amaranthus caudatus and Amaranthus cruentus) by Gamel et al. (2004) [6], the highest loss of amino acid was recorded for tyrosine followed by phenylalanine and methionine with 35\%, 24\% and 18\% loss for Amaranthus caudatus and 32\%, 20\% and 19\% for Amaranthus cruentus, respectively. Another study by Tovar et al. (1989) [26] reported highest loss for lysine (56\%) followed by arginine (29\%). Pisarikova et al. (2005) [8] also reported that the decrease in the concentration of indispensable amino acids due to heat treatment was highest for histidine followed by lysine and leucine. Despite the improvement in sensory attributes during popping, the associated loss of amino acids decreased the overall quality of amaranth proteins.

In the present study, fermentation also led to a significant decrease in the contents of the same six amino acids as that of popping (Table 2). However, after fermentation, the decrease in essential amino acids, lysine and cysteine with percent reduction of 20 and 16\%, respectively, were significantly lower than after popping ( $<$ 0.05 ) and methionine was subject to a higher (20\%) percent reduction although not statistically significant ( $<$ 0.05). The reduction could be ascribed to metabolism of amino acids by microorganisms into ammonia and volatile compounds that are responsible for the flavor of the fermented product [12].

\subsection{Effect of Popping and Fermentation on Free Amino Acid Content}

Popping and fermentation led to highly significant changes in free amino acid contents $(\mathrm{p}<0.01)$ (Table 3).

Table 2. Effect of popping and fermentation on total amino acid content ( $\mathrm{mg} \cdot \mathrm{g}^{-1}$ protein) of amaranth grains ${ }^{\dagger}$.

\begin{tabular}{|c|c|c|c|c|c|c|}
\hline \multirow{3}{*}{ Amino acid } & \multirow{3}{*}{ p-value } & \multicolumn{5}{|c|}{ Processing } \\
\hline & & \multirow{2}{*}{$\begin{array}{c}\text { Raw } \\
\text { Mean } \pm \text { SD }\end{array}$} & \multicolumn{2}{|c|}{ Popped } & \multicolumn{2}{|c|}{ Fermented } \\
\hline & & & Mean \pm SD & $\%$ variation & Mean \pm SD & $\%$ variation \\
\hline Cysteine & $0.0023^{*}$ & $46.3 \pm 6.0 \mathrm{a}$ & $29.4 \pm 8.2 \mathrm{c}$ & -37 & $38.9 \pm 15.0 \mathrm{~b}$ & -16 \\
\hline Histidine & 0.8097 & $35.3 \pm 2.7$ & $35.0 \pm 1.3$ & - & $34.6 \pm 2.8$ & - \\
\hline Isoleucine & 0.1014 & $37.2 \pm 3.0$ & $33.7 \pm 4.7$ & - & $35.4 \pm 3.2$ & - \\
\hline Leucine & 0.4034 & $62.5 \pm 4.0$ & $60.3 \pm 4.3$ & - & $60.8 \pm 5.0$ & - \\
\hline Lysine & $0.0000^{*}$ & $68.6 \pm 5.6 \mathrm{a}$ & $44.0 \pm 10.1 \mathrm{c}$ & -36 & $55.0 \pm 16.8 \mathrm{~b}$ & -20 \\
\hline Methionine & $0.0062^{*}$ & $26.1 \pm 2.8 \mathrm{a}$ & $23.0 \pm 4.1 \mathrm{~b}$ & -12 & $20.8 \pm 5.1 \mathrm{~b}$ & -20 \\
\hline Phenylalanine & 0.3940 & $43.2 \pm 2.8$ & $41.4 \pm 3.3$ & - & $41.4 \pm 4.5$ & - \\
\hline Threonine & 0.0836 & $37.3 \pm 3.1$ & $35.1 \pm 2.0$ & - & $35.4 \pm 3.3$ & - \\
\hline Tyrosine & 0.1473 & $49.5 \pm 4.8$ & $48.5 \pm 2.7$ & - & $45.7 \pm 4.8$ & - \\
\hline Valine & 0.0832 & $43.9 \pm 4.3$ & $40.2 \pm 5.5$ & - & $42.2 \pm 3.8$ & - \\
\hline Alanine & 0.3488 & $40.4 \pm 4.2$ & $38.7 \pm 2.6$ & - & $39.8 \pm 2.6$ & - \\
\hline Arginine & $0.0003^{*}$ & $104.2 \pm 8.0 \mathrm{a}$ & $88.6 \pm 11.9 b$ & -15 & $83.2 \pm 15.1 b$ & -20 \\
\hline Aspartic acid & $0.0191^{*}$ & $89.9 \pm 6.5 \mathrm{a}$ & $84.8 \pm 2.7 \mathrm{~b}$ & -6 & $83.1 \pm 5.5 b$ & -8 \\
\hline Glutamic acid & 0.0711 & $189.6 \pm 15.0$ & $183.6 \pm 6.8$ & - & $176.3 \pm 13.3$ & - \\
\hline Glycine & 0.6262 & $96.4 \pm 7.1$ & $93.8 \pm 3.7$ & - & $95.4 \pm 7.3 \mathrm{a}$ & - \\
\hline Proline & 0.0584 & $126.4 \pm 23.0$ & $112.9 \pm 15.5$ & - & $106.5 \pm 8.4$ & - \\
\hline Serine & $0.0049^{*}$ & $64.3 \pm 5.6 \mathrm{a}$ & $59.1 \pm 3.2 \mathrm{~b}$ & -8 & $57.2 \pm 3.7 \mathrm{~b}$ & -11 \\
\hline Ammonia & 0.1330 & $75.0 \pm 10.6$ & $71.9 \pm 9.5$ & - & $80.7 \pm 10.3$ & - \\
\hline
\end{tabular}

${ }^{\dagger}$ Values are means of results obtained in triplicate \pm SD for the three amaranth varieties. ${ }^{*}$ The effect of processing is significant $(\mathrm{p}<0.05)$ and means followed by different letters in the same row are significantly different at $\mathrm{p}<0.05$. 
Table 3. Effect of popping and fermentation on free amino acid content ( $\mathrm{mg} \cdot \mathrm{g}^{-1}$ protein) of amaranth grains ${ }^{\dagger}$.

\begin{tabular}{|c|c|c|c|c|c|c|}
\hline \multirow{3}{*}{ Amino acid } & \multirow{3}{*}{ p-value } & \multicolumn{5}{|c|}{ Processing } \\
\hline & & \multirow{2}{*}{$\begin{array}{c}\text { Raw } \\
\text { Mean } \pm \text { SD }\end{array}$} & \multicolumn{2}{|c|}{ Popped } & \multicolumn{2}{|c|}{ Fermented } \\
\hline & & & Mean \pm SD & $\%$ variation & Mean \pm SD & $\%$ variation \\
\hline Arginine & & $2.0 \pm 1.2 \mathrm{a}$ & $0.8 \pm 0.6 \mathrm{~b}$ & -60 & $0.3 \pm 0.1 \mathrm{c}$ & -85 \\
\hline Cysteine & & $1.0 \pm 0.3 \mathrm{~b}$ & $0.5 \pm 0.1 \mathrm{c}$ & -50 & $3.7 \pm 0.7 \mathrm{a}$ & 270 \\
\hline Histidine & & $1.4 \pm 0.2 b$ & $0.4 \pm 0.1 \mathrm{c}$ & -71 & $4.6 \pm 2.6 \mathrm{a}$ & 229 \\
\hline Isoleucine & & $0.4 \pm 0.1 \mathrm{~b}$ & $0.1 \pm 0.1 \mathrm{c}$ & -75 & $2.8 \pm 0.5 \mathrm{a}$ & 600 \\
\hline Leucine & & $0.3 \pm 0.1 \mathrm{~b}$ & $0.1 \pm 0.1 \mathrm{c}$ & -67 & $6.5 \pm 1.4 \mathrm{a}$ & 2067 \\
\hline Lysine & & $1.1 \pm 0.2 \mathrm{~b}$ & $0.7 \pm 0.2 \mathrm{c}$ & -36 & $2.0 \pm 0.6 \mathrm{a}$ & 82 \\
\hline Methionine & & $0.4 \pm 0.2 \mathrm{~b}$ & $0.1 \pm 0.1 \mathrm{c}$ & -75 & $2.6 \pm 0.5 \mathrm{a}$ & 550 \\
\hline Phenylalanine & & $0.2 \pm 0.1 \mathrm{~b}$ & $0.0 \pm 0.0 \mathrm{c}$ & -100 & $3.5 \pm 0.8 \mathrm{a}$ & 1650 \\
\hline Threonine & & $0.0 \pm 0.0 \mathrm{~b}$ & $0.0 \pm 0.0 \mathrm{~b}$ & - & $0.2 \pm 0.0 \mathrm{a}$ & 100 \\
\hline Tryptophan & $\mathrm{n}<001$ & $1.0 \pm 0.3 \mathrm{~b}$ & $0.1 \pm 0.1 \mathrm{c}$ & -90 & $2.1 \pm 0.7 \mathrm{a}$ & 110 \\
\hline Tyrosine & $P=0.01$ & $0.5 \pm 0.1 \mathrm{a}$ & $0.0 \pm 0.1 \mathrm{~b}$ & -100 & $0.5 \pm 0.4 \mathrm{a}$ & - \\
\hline Valine & & $0.6 \pm 0.1 \mathrm{~b}$ & $0.3 \pm 0.2 \mathrm{c}$ & -50 & $4.0 \pm 0.7 \mathrm{a}$ & 344 \\
\hline Alanine & & $0.9 \pm 0.3 b$ & $0.5 \pm 0.3 \mathrm{c}$ & -44 & $5.2 \pm 1.2 \mathrm{a}$ & 478 \\
\hline Aspartic acid & & $1.5 \pm 0.5 \mathrm{~b}$ & $0.5 \pm 0.2 \mathrm{c}$ & -67 & $2.3 \pm 0.5 \mathrm{a}$ & 53 \\
\hline Glutamic acid & & $3.1 \pm 1.2 \mathrm{a}$ & $0.6 \pm 0.4 \mathrm{~b}$ & -81 & $3.2 \pm 1.7 \mathrm{a}$ & - \\
\hline Glycine & & $0.9 \pm 0.4 \mathrm{~b}$ & $0.8 \pm 0.5 \mathrm{c}$ & -11 & $3.6 \pm 1.2 \mathrm{a}$ & 300 \\
\hline Ornithine & & $0.2 \pm 0.0 \mathrm{~b}$ & $0.1 \pm 0.0 \mathrm{c}$ & -50 & $2.1 \pm 1.0 \mathrm{a}$ & 950 \\
\hline Proline & & $2.5 \pm 1.0 \mathrm{a}$ & $0.4 \pm 0.3 \mathrm{c}$ & -84 & $2.4 \pm 1.3 \mathrm{~b}$ & 4 \\
\hline Serine & & $1.3 \pm 0.7 \mathrm{~b}$ & $0.3 \pm 0.2 \mathrm{c}$ & -77 & $1.7 \pm 0.3 \mathrm{a}$ & 31 \\
\hline Ammonia & & $2.2 \pm 0.8 \mathrm{~b}$ & $3.2 \pm 0.6 \mathrm{c}$ & -46 & $14.1 \pm 2.3 \mathrm{a}$ & 541 \\
\hline
\end{tabular}

${ }^{\dagger}$ Values are means of results obtained in triplicate \pm SD expressed for the three amaranth varieties. Means followed by different letters in the same row are significantly different at $\mathrm{p}<0.01$.

Popping led to a significant decrease in almost all free amino acid contents (Table 3). Free aromatic amino acids were strongly affected, phenylalanine and tyrosine completely vanished and $90 \%$ of tryptophan vanished during popping. Non-enzymatic browning reaction is the most probable explanation for the decrease in the level of free amino acids during heat treatment [27].

Conversely, fermentation increased the amount of almost all free amino acids, except tyrosine, glutamic acid and proline, which remained unchanged, and arginine, which strongly decreased (Table 3). Lysine and phenylalanine increased to a greater extent than the other free amino acids. Increased microbial enzyme activity coupled with protein hydrolysis is the likely explanation for the increase in the amount of free amino acids during fermentation [12] [28]. Hamad and Fields (1979) [29] also showed that there was a significant increase in free lysine content during fermentation in other type of cereals.

\subsection{Effect of Popping and Fermentation on in Vitro Protein Digestibility (IVPD) and Protein Digestibility Corrected Amino Acid Score (PDCAAS)}

In vitro protein digestibility (IVPD) is shown in Figure 1. When the digestibility of porridge made from raw amaranth samples was compared, it was highest for white (82.4\%) followed by red (77.6\%) and brown (71.2\%) varieties. The lower IVPD in the colored varieties might be related to the presence of higher amount of dietary 


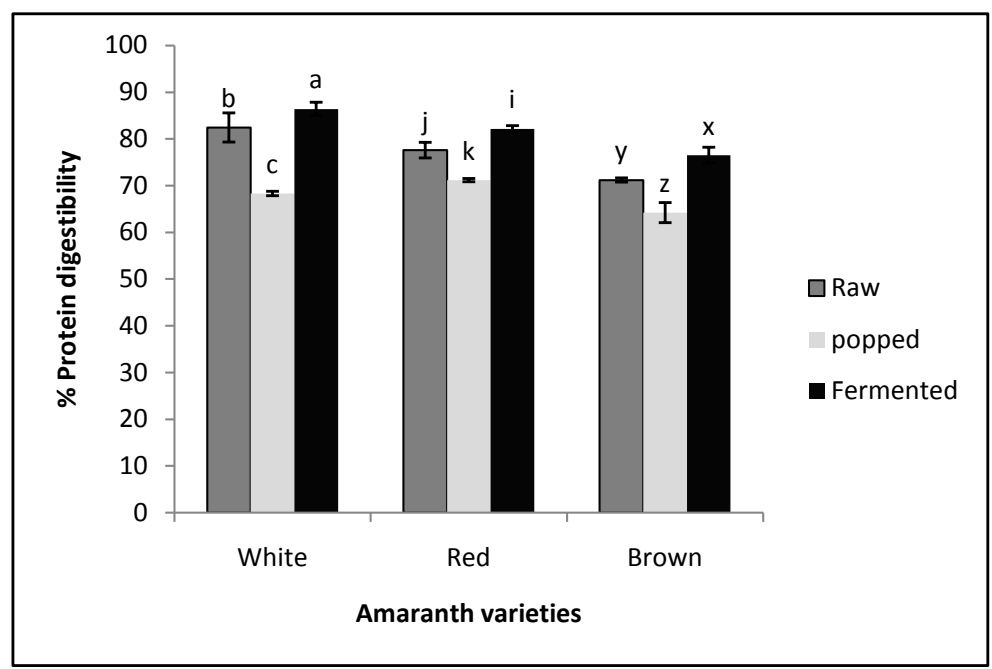

Figure 1. Effect of processing on in vitro protein digestibility (\%) in amaranth. Means with different letters are significantly different at $\mathrm{p}<0.05$ for the same variety.

fiber and polyphenols (data not shown), which could bind the protein and reduce its susceptibility to enzymatic attack [5].

Both popping and fermentation significantly affected, ( $<0.05$ ), the IVPD (Figure 1). Popping decreased protein digestibility by $17.14 \%, 8.3 \%$ and $9.8 \%$ for white, red and brown colored amaranth, respectively. This is because amino acids undergo several chemical reactions during severe heat treatment, including Maillard reaction between amino acids and reducing sugars, which reduces the availability of amino acids [27]. Therefore, during dry heat processing (popping) where the temperature often exceeds $150^{\circ} \mathrm{C}$, this reaction is likely to contribute to the decrease in protein digestibility. Unlike popping, fermentation improved IVPD by $4.8 \%, 5.9 \%$ and $7.5 \%$ for white, red and brown colored amaranth, respectively. This could be due to degradation of phytic acid (data not shown), which is a potent inhibitor of proteolytic enzymes. Besides, hydrolysis of tannins, which potentially complex proteins, may also increase the accessibility of protein molecules for enzymatic attack and hence increase IVPD [30].

In addition, hydrolysis of proteins by microorganisms during fermentation, evidenced by the increase in free amino acids, could increase IVPD. Studies by El Hag et al. (2002) [11], Pranoto et al. (2013) [12] and Hassan and El Tinay (1995) [9] on finger millet and sorghum, indeed showed that tannin hydrolysis occurs under the action of microorganisms during fermentation.

For all the indispensable amino acids, the PDCAAS, which takes both the amino acid score and protein digestibility into account, was highest for the white followed by the red and brown variety (Table 4). In all the three varieties, the popped samples had the lowest PDCAAS values due to the loss of heat labile amino acids during popping. Although there was a significant improvement $(\mathrm{p}<0.05)$ in protein digestibility during fermentation (Figure 1), the PDCAAS of almost all essential amino acids slightly increased or remained unchanged after fermentation except lysine in the brown variety, which decreased considerably. In the white and red varieties, leucine in raw samples, leucine and lysine in popped samples and leucine in fermented samples were decreased, while in the brown variety, leucine in raw samples and lysine in popped and fermented samples were decreased.

\subsection{Percentage Contribution of Amaranth as an Ingredient in Complementary Foods to the Daily Amino Acid Requirement of 6 - 23 Months old Children}

Table 5 shows the percent contribution of amaranth to the daily indispensable amino acid requirements of 6 - 23 months old children. All the three varieties of amaranth contributed more than $50 \%$ of the daily indispensable amino acid requirements based on the consumption of $50 \mathrm{~g}$ of complementary foods per day of which amaranth accounts for $32 \mathrm{~g}$. Compared to the cereals commonly used in complementary food formulation such as wheat and maize, the contribution of amaranth is appreciably higher for all indispensable amino acids except leucine 
Table 4. Percent protein digestibility corrected amino acid score (PDCAAS) for three varieties of raw and processed amaranth grains*.

\begin{tabular}{ccccccccccc}
\hline \multirow{2}{*}{ Amino acid } & \multicolumn{3}{c}{ White amaranth } & \multicolumn{3}{c}{ Red amaranth } & \multicolumn{3}{c}{ Brown amaranth } \\
\cline { 2 - 10 } & Raw & Popped & Fermented & Raw & Popped & Fermented & Raw & Popped & Fermented \\
\hline AAA $^{\S}$ & 178 & 135 & 174 & 149 & 138 & 159 & 139 & 125 & 133 \\
Histidine & 170 & 128 & 170 & 146 & 143 & 162 & 138 & 126 & 139 \\
Isoleucine & 105 & 81 & 107 & 93 & 70 & 94 & 80 & 70 & 79 \\
Leucine & 88 & 68 & 89 & 75 & 66 & 79 & 67 & 61 & 69 \\
Lysine & 117 & 68 & 110 & 100 & 66 & 104 & 89 & 40 & 49 \\
SAA & 252 & 157 & 248 & 198 & 134 & 224 & 195 & 119 & 99 \\
Threonine & 123 & 94 & 122 & 101 & 88 & 110 & 97 & 83 & 90 \\
Valine & 95 & 74 & 95 & 78 & 60 & 82 & 70 & 60 & 71 \\
\hline
\end{tabular}

*The scoring pattern for indispensable amino acids was considered for children aged 1 - 2 years [19]. " SAA: sulfur amino acids (cysteine and methionine). ${ }^{\S}$ AAA: aromatic amino acids (phenylalanine and tyrosine).

Table 5. Percentage contribution of raw amaranth to the daily indispensable amino acid requirements for children aged 6 23 months, compared to that of more commonly used cereals (maize or wheat)*.

\begin{tabular}{|c|c|c|c|c|c|c|c|c|c|c|c|}
\hline \multirow{3}{*}{$\begin{array}{c}\text { Amino } \\
\text { acid }\end{array}$} & \multicolumn{5}{|c|}{ Amount of amino acid (mg/100g DM) } & \multirow{3}{*}{ Requirement $^{s}$} & \multicolumn{5}{|c|}{ Percentage contribution $(\%)^{Y}$} \\
\hline & \multirow{2}{*}{ Wheat $^{\dagger}$} & \multirow{2}{*}{ Maize $^{\dagger}$} & \multicolumn{3}{|c|}{ Amaranth } & & \multirow{2}{*}{ Wheat } & \multirow{2}{*}{ Maize } & \multicolumn{3}{|c|}{ Amaranth } \\
\hline & & & White & Red & Brown & & & & White & Red & Brown \\
\hline AAA & 764 & 795 & 1379 & 1340 & 1400 & $458-476$ & $51-53$ & $53-56$ & $92-96$ & $90-93$ & $94-98$ \\
\hline His & 274 & 244 & 516 & 514 & 540 & $171-178$ & $49-51$ & $44-46$ & $92-96$ & $92-97$ & $98-102$ \\
\hline Ileu & 441 & 325 & 547 & 563 & 542 & $279-321$ & $44-51$ & $32-37$ & $54-62$ & $56-64$ & $54-62$ \\
\hline Leu & 811 & 1129 & 932 & 921 & 925 & $566-642$ & $40-46$ & $56-64$ & $46-53$ & $46-52$ & $46-53$ \\
\hline Lys & 334 & 244 & 1026 & 1011 & 1014 & $497-535$ & $20-22$ & $15-16$ & $61-66$ & $61-65$ & $60-65$ \\
\hline SAA & 418 & 316 & 1103 & 1008 & 1108 & $241-262$ & $51-56$ & $39-42$ & $136-148$ & $124-135$ & $135-147$ \\
\hline Thr & 346 & 334 & 559 & 531 & 570 & $264-273$ & $40-42$ & $39-41$ & $65-67$ & $62-64$ & $67-70$ \\
\hline Val & 523 & 433 & 671 & 636 & 641 & $380-428$ & $39-44$ & $32-36$ & $50-56$ & $48-54$ & $48-54$ \\
\hline
\end{tabular}

${ }^{*}$ Assuming daily consumption of $50 \mathrm{~g}$ of complementary food on a dry weight basis formulated with $64 \%$ of cereals or amaranth. ${ }^{\dagger}$ Shewry et al. (2007) [23]. ${ }^{\$}$ The lower and upper values refer to the requirements for 6 and 23 months old children, respectively [19]. ${ }^{*}$ The lower and upper values refer to the contribution of unprocessed cereals to the daily amino acid needs for 23 and 6 months old children, respectively.

(Table 5). Moreover, the daily needs of sulfur-containing amino acids were fully met by consuming the suggested amount of amaranth. However, if only the digestible fraction of protein is taken into consideration, the contribution to amino acid requirements would decrease by about $18 \%-29 \%$.

\section{Conclusion}

All three varieties of amaranth investigated in this study can be considered as a potential source of protein. Due to its high essential amino acid contents, amaranth could potentially substitute other more common cereals used in complementary food formulation for young children and thus reduce the proportion of legumes. Although popping improved the sensorial attributes of amaranth porridge, it reduced protein quality through the loss of heat labile amino acids. On the other hand, fermentation was better than popping in maintaining the amino acid profile with its added advantage of improving the protein digestibility although it resulted in a marked decrease in lysine content. 


\section{Acknowledgements}

The authors are grateful to Addis Ababa University, SIDA SAREC Swedish government, and Institut de Recherche pour le Development (IRD), Montpellier, France for supporting the study.

\section{References}

[1] Rastogi, A. and Shukla, S. (2013) Amaranth: A New Millennium Crop of Nutraceutical Values. Critical Reviews in Food Science and Nutrition, 53, 109-125. http://dx.doi.org/10.1080/10408398.2010.517876

[2] Bressani, R. (2003) Amaranth. In: Caballero, B., Ed., Encyclopedia of Food Sciences and Nutrition, Academic Press, Oxford, 166-173. http://dx.doi.org/10.1016/B0-12-227055-X/00036-5

[3] Kaur, S., Singh, N. and Rana, J.C. (2010) Amaranthus hypochondriacus and Amaranthus caudatus Germplasm: Characteristics of Plants, Grain and Flours. Food Chemistry, 123, 1227-1234. http://dx.doi.org/10.1016/j.foodchem.2010.05.091

[4] Barba de la Rosa, A.P., Fomsgaard, I.S., Laursen, B., Mortensen, A.G., Olvera-Martinez, L., Silva-Sanchez, C., MendozaHerrera, A., Gonzalez-Castaneda, J. and De Leon-Rodriguez, A. (2009) Amaranth (Amaranthus hypochondriacus) as an Alternative Crop for Sustainable Food Production: Phenolic Acids and Flavonoids with Potential Impact on Its Neutraceutical Quality. Journal of Cereal Science, 49, 117-121. http://dx.doi.org/10.1016/j.jcs.2008.07.012

[5] Pedersen, B., Kalinowski, L.S. and Eggum, B.O. (1987) The Nutritive Value of Amaranth Grain (Amaranthus caudatus). Plant Foods for Human Nutrition, 36, 309-324. http://dx.doi.org/10.1007/BF01892352

[6] Gamel, T.H., Linssen, J.P., Alink, G.M., Mosallem, A.S. and Shekib, L.A. (2004) Nutritional Study of Raw and Popped Seed Proteins of Amaranthus caudatus L. and Amaranthus cruentus L. Journal of the Science of Food and Agriculture, 84, 1153-1158. http://dx.doi.org/10.1002/jsfa.1781

[7] Písaříková, B., Kráčmar, S. and Herzig, I. (2005) Amino Acid Contents and Biological Value of Protein in Various Amaranth Species. Czech Journal of Animal Science, 50, 169-174.

[8] Písaříková, B., Zralý, Z., Kráčmar, S., Trčková, M. and Herzig, I. (2005) Nutritional Value of Amaranth (Genus Amaranthus L.) Grain in Diets for Broiler Chickens. Czech Journal of Animal Science, 50, 568-573.

[9] Hassan, I.A. and El Tinay, A.H. (1995) Effect of Fermentation on Tannin Content and In-Vitro Protein and Starch Digestibilities of Two Sorghum Cultivars. Food Chemistry, 53, 149-151. http://dx.doi.org/10.1016/0308-8146(95)90780-B

[10] El-Adawy, T.A. (2002) Nutritional Composition and Antinutritional Factors of Chickpeas (Cicerarietinum L.) Undergoing Different Cooking Methods and Germination. Plant Foods for Human Nutrition, 57, 83-97. http://dx.doi.org/10.1023/A:1013189620528

[11] El Hag, M.E., El Tinay, A.H. and Yousif, N.E. (2002) Effect of Fermentation and Dehulling on Starch, Total Polyphenols, Phytic acid Content and in Vitro Protein Digestibility of Pearl Millet. Food Chemistry, 77, 193-196. http://dx.doi.org/10.1016/S0308-8146(01)00336-3

[12] Pranoto, Y., Anggrahini, S. and Efendi, Z. (2013) Effect of Natural and Lactobacillus plantarum Fermentation on In-Vitro Protein and Starch Digestibilities of Sorghum Flour. Food Bioscience, 2, 46-52. http://dx.doi.org/10.1016/j.fbio.2013.04.001

[13] Nunes, A., Correia, I., Barros, A. and Delgadillo, I. (2004) Sequential in Vitro Pepsin Digestion of Uncooked and Cooked Sorghum and Maize Samples. Journal of Agricultural and Food Chemistry, 52, 2052-2058. http://dx.doi.org/10.1021/jf0348830

[14] Ibrahim, F.S., Babiker, E.E., Yousif, N.E. and El Tinay, A.H. (2005) Effect of Fermentation on Biochemical and Sensory Characteristics of Sorghum Flour Supplemented with Whey Protein. Food Chemistry, 92, 285-292. http://dx.doi.org/10.1016/j.foodchem.2004.07.024

[15] Mouquet, C. and Trèche, S. (2001) Viscosity of Gruels for Infants: A Comparison of Measurement Procedures. International Journal of Food Sciences and Nutrition, 52, 389-400. http://dx.doi.org/10.1080/09637480120078276

[16] Berghofer, E. and Schoenlechner, R. (2002) Grain Amaranth. In: Belton, P. and Taylor, J., Eds., Pseudocereals and Less Common Cereals: Grain Properties and Utilization Potential, Springer, New York, 219-260. http://dx.doi.org/10.1007/978-3-662-09544-7_7

[17] Moore, S., Spackman, D.H. and Stein, W.H. (1958) Chromatography of Amino Acids on Sulfonated Polystyrene Resins. An Improved System. Analytical Chemistry, 30, 1185-1190. http://dx.doi.org/10.1021/ac60139a005

[18] Akeson, W.R. and Stahmanna, A.A. (1964) Pepsin Pancreatin Digest Index of Protein. Journal of Nutrition, 83, 257261.

[19] WHO (2007) Protein and Amino Acid Requirements in Human Nutrition. World Health Organization Technical Re- 
port Series 935, No. 1.

[20] Lutter, C.K. and Dewey, K.G. (2003) Proposed Nutrient Composition for Fortified Complementary Foods. The Journal of Nutrition, 133, 3011S-3020S.

[21] Nguyen, V.H. (2013) Technical Specifications for the Manufacture of Super Cereal, Version 13. http://foodqualityandsafety.wfp.org

[22] Iqbal, A., Khalil, I.A., Ateeq, N. and Khan, M.S. (2006) Nutritional Quality of Important Food Legumes. Food Chemistry, 97, 331-335. http://dx.doi.org/10.1016/j.foodchem.2005.05.011

[23] Shewry, P.R. (2007) Improving the Protein Content and Composition of Cereal Grain. Journal of Cereal Science, 46, 239-250. http://dx.doi.org/10.1016/j.jcs.2007.06.006

[24] Chávez-Jáuregui, R., Silva, M. and Areas, J.A.G. (2000) Extrusion Cooking Process for Amaranth (Amaranthus caudatus L.). Journal of Food Science, 65, 1009-1015. http://dx.doi.org/10.1111/j.1365-2621.2000.tb09408.x

[25] Nimbalkar, M.S., Pai, S.R., Pawar, N.V., Oulkar, D. and Dixit, G.B. (2012) Free Amino Acid Profiling in Grain Amaranth Using LC-MS/MS. Food Chemistry, 134, 2565-2569. http://dx.doi.org/10.1016/j.foodchem.2012.04.057

[26] Tovar, L.R., Brito, E., Takahashi, T., Miyazawa, T., Soriano, J. and Fujimoto, K. (1989) Dry Heat Popping of Amaranth Seed Might Damage Some of Its Essential Amino Acids. Plant Foods for Human Nutrition, 39, 299-309. http://dx.doi.org/10.1007/BF01092066

[27] Ibanoglu, S., Ainsworth, P. and Hayes, G.D. (1997) In Vitro Protein Digestibility and Content of Thiamine and Riboflavin in Extruded Tarhana a Traditional Turkish Cereal Food. Food Chemistry, 58, 141-144. http://dx.doi.org/10.1016/S0308-8146(96)00233-6

[28] Sripriya, G., Antony, U. and Chandra, T.S. (1997) Changes in Carbohydrate, Free Amino Acids, Organic Acids, Phytate and $\mathrm{HCl}$ Extractability of Minerals during Germination and Fermentation of Finger Millet (Eleusine coracana). Food Chemistry, 58, 345-350. http://dx.doi.org/10.1016/S0308-8146(96)00206-3

[29] Hamad, A.M. and Fields, M.L. (1979) Evaluation of the Protein Quality and Available Lysine of Germinated and Fermented Cereals. Journal of Food Science, 44, 456-459. http://dx.doi.org/10.1111/j.1365-2621.1979.tb03811.x

[30] Duodu, K.G., Taylor, J.R.N., Belton, P.S. and Hamaker, B.R. (2003) Factors Affecting Sorghum Protein Digestibility. Journal of Cereal Science, 38, 117-131. http://dx.doi.org/10.1016/S0733-5210(03)00016-X 
Scientific Research Publishing (SCIRP) is one of the largest Open Access journal publishers. It is currently publishing more than 200 open access, online, peer-reviewed journals covering a wide range of academic disciplines. SCIRP serves the worldwide academic communities and contributes to the progress and application of science with its publication.

Other selected journals from SCIRP are listed as below. Submit your manuscript to us via either submit@scirp.org or Online Submission Portal.
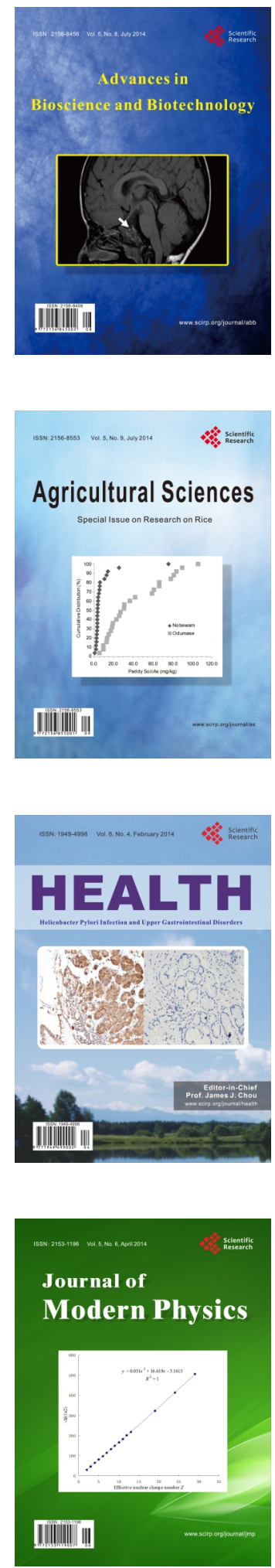
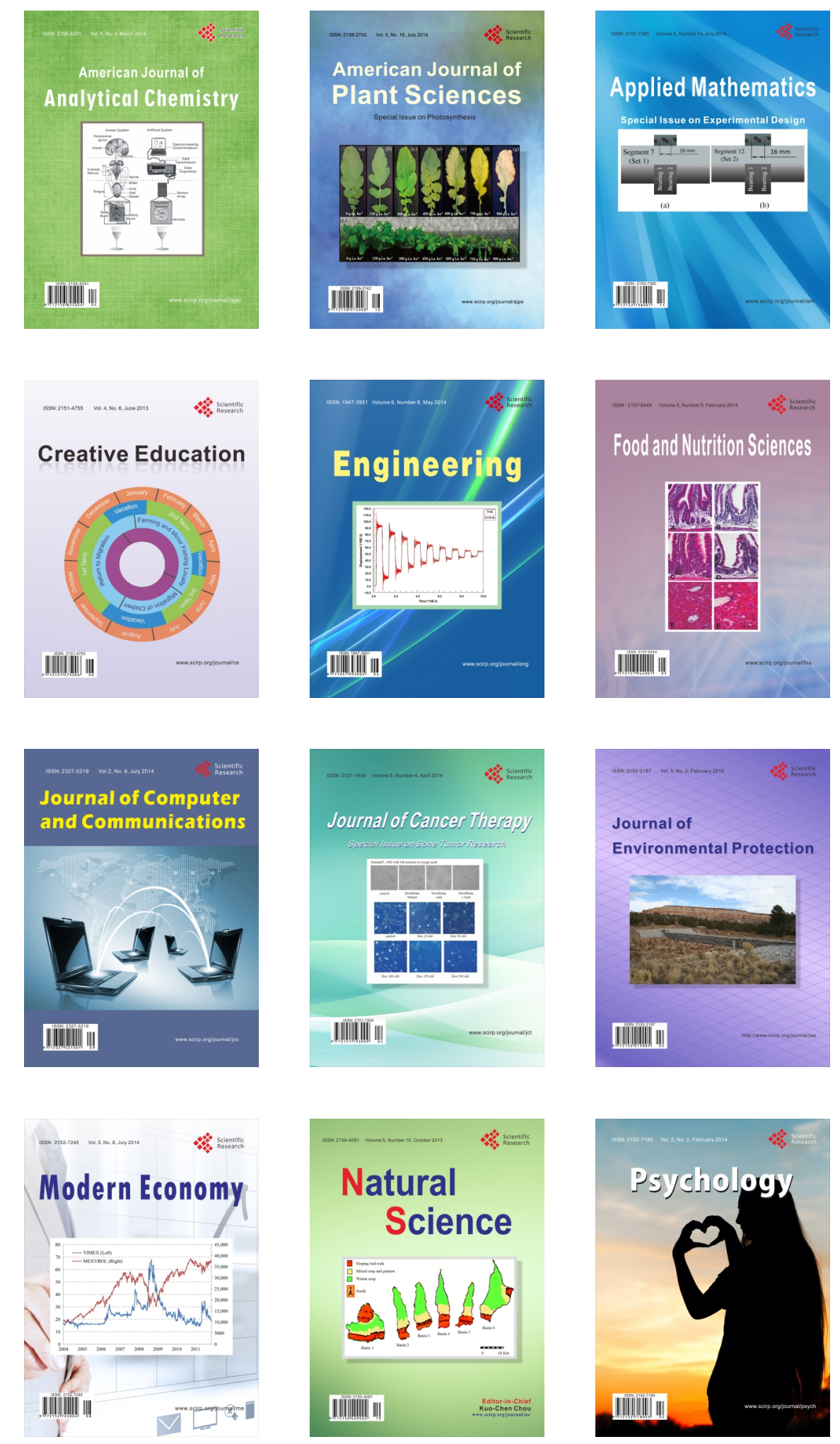